\title{
States of conflict: gender, violence and resistance
}

Susie Jacobs, Ruth Jacobson, and Jennifer Marchbank (Eds.); Zed Books, London, New York, 2000 , ix + 246 pp, £14.95 pb, ISBN 1-85649-656-2

This is an ambitious book, with a very broad reach and yet it manages to be extremely coherent. A significant strength is its geographical reach, with contributions on Africa, Brazil, Northern Ireland, India, China and the US. However, it is also broad in terms of the perspectives covered. The 12 Chapters bring together authors from a wide range of disciplines and cover an impressive array of themes under the umbrella of conflict with the focus on gender. Theoretical discussions are anchored in particular case studies of women in the military, women asylum seekers, women and resistance and women and private and public violence, while the role of the state both in sanctioning and using violence against women is explored in a number of chapters.

The introduction by the three editors raises interesting and provocative questions about power, violence and resistance that are addressed, more or less successfully by the rest of the contributors. Although the editors claim that the book does not take one definite position on 'violence' and whether it should be confined to physical acts or broadened to include cruelty and abuse, nonetheless, most of the contributors focus on physical manifestations - whether sexual violence as in the chapter by Kelly, domestic violence in Brazil and South Africa or the violence of war as in the chapter by $દ 1$-Bushra. However conceptualized and wherever located, each of the contributors place this violence within the context of a state system that, at best tolerates, and at worst promotes violence against women.

Most of the contributors also focus on women as victims or resisters, but some acknowledge the role of women as perpetrators of violence. Mukta reveals the violence of Hindu women in India, both as family members and as guardians of Hindutva. In this paper, upper caste women not only goad Hindu men to acts of aggression, but commit such acts themselves, occasionally on themselves (selfimmolation). Jacobson, writing on the Northern Ireland Peace Process, while reflecting on women's roles as peace-makers, also considers their involvement in tolerating and encouraging violent acts.

In the case study of South Africa by Maitse, African women are not the active, aggressive agents depicted by Mukta. Instead they are victims of apartheid, of nationalism and of their male partners. Maitse outlines the links between the three forms of oppression experienced by the women she interviewed, some of whom were active participants in the national liberation struggle.

Heaven Crawley's paper places, justifiably, considerable emphasis on the role of the state as persecutor, but it also becomes clear that the construction of refugee by the international regime as a victim of a state's persecution for political activities fails to take account of sexual violence as a state instrument. This has 
been compounded by the failure of courts to recognize that women are not solely dependents, but are also political actors in their own right. Crawley acknowledges that there has been some movement towards a recognition of certain groups of women as 'social groups' according to the 1951 Convention (for example the case of Shah Islam in Britain), but stresses the significance of the public/private divide for women seeking asylum in Western countries.

All of the contributions to this volume problematize state and nation, though it is the latter that emerges from these contributions as the most damaging in terms of women's identity. The construction of the nation as a natural entity seems inevitably to depend for its continuance on women, but their function within this scheme is reproductive, both physically and in transmitting the values of the nation to new generations (Jacobson, Maitse, Mukta). While the nation seems to constitute an unequivocal danger to women, the state seems redeemable for some. Macaulay on Brazil and Howell on China chronicle the attempts of women to work through the state. In the first case, Macaulay discusses the attempts of women's NGOs to pressurise government at local and national level to respond to violence against women, resulting, for example, in the creation of women's police stations. Howell considers the work of the All-China Women's Federation, which represents women's issues. In each case, while progress has been achieved, the authors conclude that the constraints of operating within traditional state structures make such progress extremely slow.

What emerges clearly from this collection of very different voices is the continuing need to embrace a radical agenda.

Liza Schuster

doi: $10.1057 /$ palgrave.fr. 9400093

\section{Saving Bernice: battered women, welfare and poverty}

Jody Raphael; Northeastern University Press, Boston, MA 2000, £14.50 pbk, ISBN 1-55553438-4, £39.00 hbk, ISBN 1-55553-439-2, 184pp

This book looks at the impact of domestic violence on mothers attending welfare to work programmes in the US. By focussing on the story of one African-American mother on welfare - Bernice, Jody Raphael sets out to challenge a number of received wisdoms about mothers living on welfare, domestic violence and poverty, and to cover a range of connected issues. She argues that many women in receipt of welfare payments who had previously been viewed as 'single' mothers do in fact have partners, and suggests that US survey evidence shows that between $20 \%$ and 